\title{
DEVELOPMENT OF THE COMPOSITION OF THE DRUG WITH THE IMMUNOMODULATORY ACTION IN THE FORM OF GRANULES BASED ON BEE BREAD
}

\author{
B.T.Kudrik, O.I.Tikhonov \\ National University of Pharmacy \\ Key words: bee bread; granules; physico-chemical studies; pharmacotechnological studies
}

\begin{abstract}
The current literary sources have been analysed. The choice of the substance as the main active ingredient for preparing a drug with the immunomodulatory action in the form of granules has been substantiated. The study of physico-chemical and pharmaco-technological properties of granules with bee bread has been conducted. Based on the SPhU method the experimental research in studying fluidity, the value of the angle of repose, bulk volume before and after settling, directly settling qualities, moisture absorption and moisture content of granulated and common bee bread has been performed. Dependence of moisture absorption of the drug samples in the form of granules on time has been studied; disintegration of the test samples of the drug with the immunomodulatory action based on bee bread granules has been investigated. With the help of the combination of active substances the indicators of fluidity have been maximally improved; it is considerably necessary for further development of the drug. It has been shown how the excipients and the method of granulation affect the technological properties and quality of the drug. Superiority of granulated bee bread over common bee bread has been studied and experimentally proven by all physico-chemical parameters and technological properties. The optimal compositions for obtaining an immunomodulator have been analysed and selected. The samples of granules with bee bread have been obtained and studied. With the help of physico-chemical and pharmaco-technological investigations the choice of one sample and the composition of the drug in the form of granules for use as an immunomodulator has been scientifically substantiated.
\end{abstract}

Immunity is the most important factor for existence of all living beings. The essence of its functioning is to identify, process and remove a foreign body from the organism. This process of host defense occurs both by the natural way (i.e., by means of innate immunity) and artificially (by means of acquired immunity). Both types of immunity always work in pairs, complementing each other. Thus, innate immunity performs its work at the stage of disease (i.e., the initial stage) and at the stage of recovery (the final stage), and acquired immunity performs the intermediate function, it identifies and remembers the virus passed into the body in order the organism to be ready for reinfection in future.

The main organs in the complex mechanism of the immune system are lymph nodes, bone marrow, spleen, thymus gland. They are the first to react to changes in the defence system of immunity. Moreover, all unfavourable factors affecting the immune system are reflected exactly on these organs. Such factors include bad ecological situation; the lack of proteins, vitamins, minerals, amino acids, macro- and microelements; poor nutrition; overstrain and stress; different chronic diseases; infectious diseases.

Besides, in case of frequent exacerbation of chronic diseases (for example, frequent appearance of herpes or frequent bronchitis), it also indicates that defence of the organism is not in good order. This list includes also such important signs as constant exposure to stresses and constant fatigue.
So, what should be done to increase the body's resistence and prevent weakening of immunity? The main natural products that reinforce the immune system are the products of apiculture; among them bee bread is the most useful for the immune system.

Bee bread is pollen collected by bees and proccessed by lactic fermentation, it is preserved in the combs under a layer of honey. This product is unique by its composition, it is almost impossible to produce it artificially. Bee bread contains the basic vitamins for immunity improvement (A, C, P, E, as well as B vitamins), the complex of amino acids, minerals, macro- and microelements. Bee bread helps the resistance of the immune system to various pathogens as it exhibits the antimicrobial properties.

A wide distribution and occurrence of new infectious diseases, appearance of antibiotic-resistant strains of pathogenic microorganisms, as well as development of severe complications in immunodeficient patients with infectious and non-infectious pathology cause the urgent need to use immunomodulatory and immunostimulating drugs when treating people.

The current synthetic drugs with the immunomodulatory and immunostimulating action are famous for the fact that for a time they build up a tolerance, and bacteria also cease to react to them after some time. But bee bread is valuable because it does not cause tolerance in microorganisms and can fight against them for a long time. 
Table 1

Physico-chemical and pharmacotechnological properties of active substances

\begin{tabular}{|l|c|c|}
\hline \multirow{2}{*}{ The name of the indicator } & \multicolumn{2}{|c|}{ Values } \\
\cline { 2 - 3 } & bee bread & $\begin{array}{c}\text { granulated } \\
\text { bee bread }\end{array}$ \\
\hline Fluidity, $\mathrm{g} / \mathrm{s}$ & infinite & $1.98 \pm 0.03$ \\
\hline Angle of repose, degrees & absent & $36.04 \pm 0.9$ \\
\hline Bulk volume, $\left(\mathrm{V}_{0}\right), \mathrm{ml}$ & $175.20 \pm 2.80$ & $175.45 \pm 4.80$ \\
\hline Settled volume, $\left(\mathrm{V}_{10}\right), \mathrm{ml}$ & $169.64 \pm 2.80$ & $168.05 \pm 2.30$ \\
\hline Settled volume, $\left(\mathrm{V}_{500}\right), \mathrm{ml}$ & $143.30 \pm 3.30$ & $158.32 \pm 2.56$ \\
\hline Settled volume, $\left(\mathrm{V}_{1250}\right), \mathrm{ml}$ & $139.15 \pm 4.22$ & $157.34 \pm 1.81$ \\
\hline Settling qualities, $\left(\mathrm{V}_{10} \mathrm{~V}_{500}\right), \mathrm{ml}$ & $29.73 \pm 2.83$ & $11.65 \pm 1.41$ \\
\hline Bulk density, $\left(\mathrm{m} / \mathrm{V}_{0}\right), \mathrm{g} / \mathrm{ml}$ & $0.53 \pm 0.01$ & $0.58 \pm 0.01$ \\
\hline Tapped density, $\left(\mathrm{m} / \mathrm{V}_{1250}\right), \mathrm{g} / \mathrm{ml}$ & $0.71 \pm 0.01$ & $0.64 \pm 0.01$ \\
\hline $\begin{array}{l}\text { Moisture absorption in } 100 \%, \\
\text { rel. hum., } 20^{\circ} \mathrm{C}, \%\end{array}$ & $3.15 \pm 0.35$ & $14.58 \pm 1.10$ \\
\hline Moisture content, $\%$ & $19.15 \pm 1.10$ & $4.25 \pm 0.21$ \\
\hline
\end{tabular}

Note. The number of measurements $n=5, P=95 \%$.

To solve the problem of immunodeficiency there is a need in creating the composition and technology of a new, cheap, natural and promising drug for improving the immune properties of a human organism based on such apiculture product as bee bread described above.

That is why in the research laboratory of the National University of Pharmacy under the supervision of academician of the NAS of Ukraine, Doctor of Pharmacy, professor of the NUPh, O.I.Tikhonov the composition of a solid drug with the immunomodulatory action has been developed on the basis of bee bread and the properties of the active substance in the granulated form have been maximally studied.

\section{Experimental Part}

The study of fluidity of the active substance and the samples of granules was performed according to the method of the SPhU (p. 2.9.16, art. 163-164), using the funnel method with a shaker [3]. To improve the fluidity of the mix- ture of the active substances the studies were conducted adding such antifriction substances and excipients as aerosil, microcrystalline cellulose, mannitol, as well as such fillers as lactose monohydrate, potato starch, sucrose, which, in their turn, were also the sweeteners in the composition of the drug being developed. Using protractor the value of the angle of repose was also determined.

The bulk volume, settling qualities, bulk density and tapped density of the mixture of the active substances were determined according to the method of the SPhU (p. 2.9.15, art. 163-163) using a 545P-AK-3 device [3]. The research results obtained are given in Tab. 1.

To determine the value of moisture absorption the mixture of the active substances with regulators of humidity was placed in the previously weighed weighing bottles with the diameter of $29 \pm 0.5 \mathrm{~mm}$ and the height of $35 \mathrm{~mm}$ and the desiccator with the diameter of $140 \mathrm{~mm}$. The research was conducted under the following conditions: ambient temperature $-18-20^{\circ} \mathrm{C}$, humidity $-100 \%$ created with the help of purified water. The moisture content in the reference substances and the test samples was determined according to the method of the $\mathrm{SPhU}$ (p. 2.9.36, art. 58-59) using a VT-500 device $[3,10,13]$.

\section{Results and Discussion}

The results of studying physico-chemical and pharmacotechnological properties of active substances (fluidity, angle of repose, bulk volume, bulk density, settling qualities, moisture absorption and moisture content) are given in Tab. 1.

As seen from the data of Table 1, granulated bee bread (DSTU (State Standards of Ukraine) 7074:2009) has better technological properties than common bee bread according to the values of pharmacotechnological parameters, therefore, the use of previously granulated bee bread is more rational when developing the composition of a new drug in the form of granules.

The next stage of our research was distribution of the active substance in the ratio substantiated previously. Then such excipients as aerosil and microcrystalline cellulose were added into the composition of the mixture to improve its fluidity. Using of the substances men-

Table 2

Physico-chemical and pharmacotechnological properties of granules

\begin{tabular}{|l|c|c|c|}
\hline \multicolumn{1}{|c|}{ The name of the indicator } & Composition 1 & Composition 2 & Composition 3 \\
\hline Fluidity, $\mathrm{g} / \mathrm{s}$ & $3.07 \pm 0.11$ & $4.46 \pm 0.27$ & $3.35 \pm 0.19$ \\
\hline Angle of repose, degrees & $35.0 \pm 1.0$ & $28.9 \pm 1.9$ & $32.8 \pm 0.7$ \\
\hline Bulk volume, $\left(\mathrm{V}_{0}\right), \mathrm{ml}$ & $287.03 \pm 4.07$ & $278.04 \pm 9.48$ & $276.88 \pm 2.57$ \\
\hline Settled volume, $\left(\mathrm{V}_{10}\right), \mathrm{ml}$ & $281.24 \pm 3.91$ & $270.18 \pm 3.36$ & $268.28 \pm 2.85$ \\
\hline Settled volume, $\left(\mathrm{V}_{500}\right), \mathrm{ml}$ & $262.08 \pm 4.64$ & $257.16 \pm 5.23$ & $248.40 \pm 1.98$ \\
\hline Settled volume, $\left(\mathrm{V}_{1250}\right), \mathrm{ml}$ & $257.55 \pm 3.35$ & $248.38 \pm 2.36$ & $240.14 \pm 2.98$ \\
\hline Settling qualities, $\left(\mathrm{V}_{10}-\mathrm{V}_{500}\right), \mathrm{ml}$ & $18.53 \pm 0.85$ & $13.72 \pm 1.14$ & $19.58 \pm 0.65$ \\
\hline Bulk density, $\left(\mathrm{m} / \mathrm{V}_{0}\right), \mathrm{g} / \mathrm{ml}$ & $0.34 \pm 0.01$ & $0.36 \pm 0.01$ & $0.36 \pm 0.01$ \\
\hline Tapped density, $\left(\mathrm{m} / \mathrm{V}_{1250}\right), \mathrm{g} / \mathrm{ml}$ & $0.39 \pm 0.01$ & $0.40 \pm 0.01$ & $0.40 \pm 0.01$ \\
\hline Moisture absorption in $100 \%$ rel. hum., $20^{\circ} \mathrm{C}, \%$ & $8.61 \pm 0.58$ & $3.35 \pm 0.43$ & $4.45 \pm 0.75$ \\
\hline Moisture content, $\%$ & $4.02 \pm 0.19$ & $1.93 \pm 0.09$ & $3.09 \pm 0.14$ \\
\hline
\end{tabular}

Note. The number of measurements $n=5, P=95 \%$. 


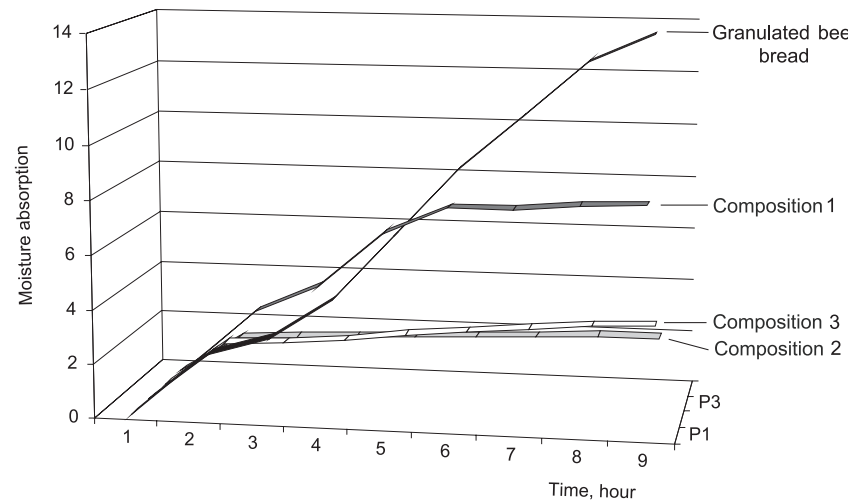

Fig. 1. Dependence of moisture absorption of the drug samples in the form of granules on time.

tioned did not help to achieve significant improvement of fluidity of the mixture.

To achieve the purpose the method of wet granulation was used. As wetting agents Plasdone K 29/32 alcohol solution (composition 1), Plasdone $\mathrm{K} 29 / 32$ aqueous solution (composition 3) and 70\% ethyl alcohol (composition 2) were used.

With the purpose of studying physico-chemical and pharmacotechnological properties the samples of a new drug with the immunomodulatory action obtained in the form of granules were carefully researched. The results are given in Tab. 2.

As seen from Tab. 2, composition 2 of granules is significantly different from the rest by some indicators, namely fluidity is much better and sufficient for dosing the drug in industrial conditions, its settling qualities are less than in other samples, therefore, it indicates the less settling qualities.

Sample No.2 also has the least value of moisture absorption and moisture content (Fig. 1), and it has a positive effect on the shelf life and storage conditions of the drug.

The indicators of the pharmacotechnological properties of the drug have been achieved by the combination of the active substance and wet granulation using $70 \%$ alcohol.

The indicators of pharmacotechnological properties of the drug have been achieved by the combination of the following excipients, namely aerosil as an antifriction substance and humidity regulator; lactose used simultaneously as a filler and a flavour (a sweetener), it has an

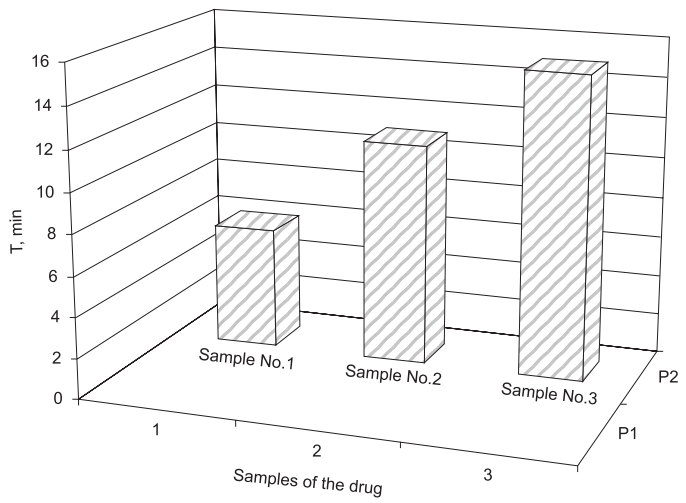

Fig. 2. Disintegration of the test samples of the drug with the immunomodulatory action in the form of granules.

additional positive effect on improvement of the granules fluidity.

Further disinegration of a new drug in the form of granules was studied, the results are presented in Fig. 2.

As seen from the data of Fig. 2, sample No.1 has the best indicator of disintegration, it is explained by the rational choice of a wetting agent $-70 \%$ alcohol, which additionally purifies the drug.

Moreover, the use of Plasdone K 29/32 solutions with different concentrations (from 1 to $5 \%$ ) as a wetting agent allows to obtain too strong granules, which have very slow disintegration. It negatively affects the rate of the drug absorption, and consequently, inhibit the rate of onset of the therapeutic effect expected.

\section{CONCLUSIONS}

1. The literary sources concerning the causes of occurrence and development of immunodeficiency and the possibility for its prevention and treatment using immunostimulating and immunomodulatory drugs have been studied, analysed and generalized.

2. The choice of the active substance for developing the composition of granules with the immunomodulatory action on its basis has been maximally substantiated.

3 . The physico-chemical and pharmacotechnological studies have been conducted with the purpose of selecting excipients in the composition of the drug being developed.

4. The necessity of wet granulation using $70 \%$ alcohol as a wetting agent required for development of the composition and formulation of a new drug with the immunomodulatory action has been proven.

\section{REFERENCES}

1.Беседнова Н.Н. // Антибиотики и химиотерапия. - 1999. - №1. - C. 31-35.

2. Вершигора А.Е. Общая иммунология: Учеб. пособие. - К.: Вища шк., 1990. - 736 с.

3. Воробьев А.А. Эндогенные иммуномодуляторы. - С.Пб.: Гиппократ, 1992. - 255 с.

4. Державна фармакопея Украйни / Державне підприємство «Науково-експертний иентр». - 1-е вид. X.: РІРЕГ, 2001. - 556 c.

5. Косарева О.В. // Известия Самарского научного иентра Российской академии наук. - 2009. - T. 11, №1 (6). C. $1224-1226$.

6. Тихонов О.І., Ярних Т.Г., Черних В.П. та ін. Теорія та практика виробництва лікарських препаратів прополісу / За ред. О.І.Тихонова. - Х.: Основа, 1998. - 384 c.

7. Ferrero C., Munoz N., Velasko M.V. et al. // Int. J. Pharm. - 1997. - №147. - P. 11-21. 
8. Gordon M.S., Rudraraju V.S., Dani K., Chowhan Z.T. // Pharm. Sci. - 1993. - No82 (2). - P. 220-226.

9. Handbook of Pharmaceutical Excipients. 6-th ed. / Ed. by Ainley Wade, Paul J. Weller. American Pharmaceutical Association. - Washington: The Pharmaceutical Press, London, 2006. - 651 p.

10. Hay W.P., Mueller P.O., Harmon B., Amoroso L. // Vet. Sung. - 2001. - №673 (3). - P. 223-227.

11. Liu L.S., Berg R.A. // Biomed. Mater. Res. - 2002. - №63 (3). - P. 326-332.

12. Pharmaceutische Technologie für Studium und Beruf / R. Voigt. Unter Mitarb. von M. Bornschein. 8. Aufl. Berlin: Wiesbaden: Ullstein Mosby, 1995. - 794 S.

13. Poongothai J. // Singapore Med. J. - 2009. - №50 (4). - P. 336-347.

\section{РОЗРОБКА СКЛАДУ ЛІКАРСЬКОГО ІМУНОМОДУЛЮЮЧОГО ЗАСОБУ У ФОРМІ ГРАНУЛ НА ОСНОВІ ПЕРГИ \\ Б.Т.Кудрик, О.І.Тихонов \\ Ключові слова: перга; гранули; фрізико-хімічні дослідження; фрармакотехнологічні}

дослідження

Проаналізовані сучасні літературні дані. Аргументований вибір субстанції в якості основної діючої речовини для приготування лікарського імуномодулюючого препарату у формі гранул. Проведено вивчення фрізико-хімічних і фрармакотехнологічних властивостей гранул з пергою. За методикою ДФУ проведені експериментальні дослідження з вивчення плинності, величини кута природного укосу, насипного об'єму до і після усадки, безпосередньо здатності до усадки, вологопоглинання та вологовмісту перги гранульованої і перги звичайної. Вивчена залежність вологопоглинання зразків препарату у формі гранул від часу, а також розпад досліджуваних зразків препарату імуномодулюючої дії на основі гранул перги. За допомогою комбінації діючих речовин були максимально поліпшені показники плинності, що дуже необхідно для подальшої розробки препарату. Показано, як впливають допоміжні речовини і спосіб гранулювання на технологічні властивості та якість препарату. Вивчено та експериментально доведено перевагу перги гранульованої над пергою звичайною за всіма фрізико-хімічними показниками та технологічними властивостями. Проаналізовані та відібрані оптимальні склади для отримання імуномодулюючого засобу. Отримані та вивчені зразки гранул з пергою. За допомогою проведення фрізико-хімічних і фрармакотехнологічних досліджень науково доведений вибір одного зразка та складу лікарського препарату у формі гранул для використання в якості імуномодулюючого засобу.

\section{РАЗРАБОТКА СОСТАВА ЛЕКАРСТВЕННОГО ИММУНОМОДУЛИРУЮЩЕГО СРЕДСТВА В ФОРМЕ ГРАНУЛ НА ОСНОВЕ ПЕРГИ Б.Т.Кудрик, А.И.Тихонов \\ Ключевые слова: перга; гранулы; фризико-химические исследования; фрармакотехнологические исследования}

Проанализированы современные литературные данные. Аргументирован выбор субстанции в качестве основного действующего вещества для приготовления лекарственного иммуномодулирующего препарата в форме гранул. Проведено изучение фризико-химических и фрармакотехнологических свойств гранул с пергой. По методике ДФУ проведены экспериментальные исследования по изучению течения, величины угла природного укоса, насыпного объема до и после усадки, непосредственно способности к усадке, влагопоглощения и влагосодержания перги гранулированной и перги обычной. Изучена зависимость влагопоглощения образцов препарата в фоорме гранул от времени, а также распад исследуемых образцов препарата иммуномодулирующего действия на основе гранул перги. С помощью комбинации действующих веществ максимально улучшены показатели течения, что очень сильно необходимо для дальнейшей разработки препарата. Показано, как влияют вспомогательные вещества и способ гранулирования на технологические свойства и качество препарата. Изучено и экспериментально доказано превосходство перги гранулированной над обычной по всем физико-химическим показателям и технологическим свойствам. Проанализированы и отобраны оптимальные составы для получения иммуномодулирующего средства. Получены и изучены образцы гранул с пергой. С помощью проведения физико-химических и фрармакотехнологических исследований научно доказан выбор одного образца и состава лекарственного препарата в форме гранул для использования в качестве иммуномодулирующего средства. 